\title{
Evaluation of Some Performance Traits and Carcass Characteristics of Archachatina marginata Snails Fed Plant Wastes
}

\author{
Olubukola Omolara Babalola ${ }^{1,2}$ \\ ${ }^{1}$ Department of Biological Sciences, Landmark University, Omu-Aran, Kwara State, Nigeria \\ ${ }^{2}$ Department of Science Technology, Federal Polytechnic, Ado-Ekiti, Ekiti State, Nigeria
}

Email address:

babalola.olubukola@lmu.edu.ng,olubukolababalola2@gmail.com

To cite this article:

Olubukola Omolara Babalola. Evaluation of Some Performance Traits and Carcass Characteristics of Archachatina marginata Snails Fed Plant Wastes. American Journal of Agriculture and Forestry. Vol. 3, No. 4, 2015, pp. 151-155. doi: 10.11648/j.ajaf.20150304.15

\begin{abstract}
There is inadequate information on quality feedstuffs for large scale production and all year round availability of snails in Nigeria. This study evaluated the performance, carcass analysis and sensory evaluation of cooked meat of growing Archachatina marginata snails fed plant wastes as a sole feed ingredient. 120 growing snails of mean weight of $132.91 \pm 2.13 \mathrm{~g}$ were randomly allotted to 4 dietary treatments of pawpaw leaves (PL), whole lettuce (WL), lettuce wastes (LW) and cabbage wastes $(\mathrm{CW})$. Each treatment was replicated thrice with 10 snails per replicate in a completely randomized design. The feeding trial lasted 6 months. Treatment effect on shell length and width was significant $(\mathrm{P}<0.05)$ with snails on LW recording highest while no significant differences were observed in the shell thickness gain $(\mathrm{P}>0.05)$. The highest dressing percentage of $43.2 \%$ was obtained for snails on LW while the lowest value of $35.19 \%$ was recorded for snails on PL. The treatments had no appreciable effect on the nutrient composition and sensory quality of the snail meat. The highest dry matter digestibility of $83.50 \%$ was recorded in snails on $\mathrm{CW}$ which was statistically similar to those on $\mathrm{LW}(83.33 \%)$ while the least value of $78.33 \%$ was recorded in snails on PL. The weight gain and feed per gain followed the same pattern as the dry matter digestibility. It can be concluded that growing snails can utilize lettuce waste as well as cabbage waste as sole feed thereby increasing the feed data base for snail production in the Tropics.
\end{abstract}

Keywords: Pawpaw leaves, Lettuce, Cabbage, Archachatina marginata Snails, Feed per Gain

\section{Introduction}

Large scale snail farming is needed in order to meet the animal protein need in human diet. There is a dearth in the supply of conventional feed concentrates which has greatly affected animal production in the tropics. This low level of livestock production in the tropics cannot meet the needs of the rapidly growing human populations. There is therefore the need to source for cheaper alternative sources of animal protein.

Snails are invertebrates with a soft body and a covering of hard shell. It is one of the micro livestock that has recently attracted attention among agriculturists in Nigeria as an aftermath of alarm raised by Food and Agricultural Organization (FAO) on animal protein deficiency among Nigerians $[1,4]$. It has small body size and is easy to handle and manage. It is found in a cool environment, in gardens, vegetable plantation, refuse heap, orchards, etc. They require humid environment and thrive well on decay materials $[3,7$, 12].

Snail meat is tender and tastes good. It is highly nutritious and when eaten serve as a special delicacy in the diet. Several studies have been conducted on snails in the last three decades. Ajayi et al. (1978) indicated that snail meat is particularly rich in protein, iron, calcium and phosphorous [2]. Snail meat has a protein content of about $18-20 \%[7,8,9]$ which compare quite well with protein contents of conventional meat such as beef (18\%), mutton $(18 \%)$ and poultry (20\%) [13] Imevbore and Ademosun (1988) reported a fat content of $1.36 \%$ which is lower than the corresponding values of $9.6 \%, 21.4 \%$ and $23 \%$ obtained for egg, mutton, and duck respectively $[14,16[]$. The study also showed that snail meat is low in saturated fatty acids $(28.71 \%)$ and cholesterol $(20.28 \mathrm{mg} / 100 \mathrm{~g}$ fresh sample) when compared 
with beef, goat meat, mutton, pork, broiler meat and fish. The low contents of fat and cholesterol make snail meat a good antidote for vascular diseases such as heart attack, cardiac arrest, hypertension and stroke [5]. Soup prepared with snail meat is a good source of iron for pregnant and nursing mothers [19].

Unfortunately, in spite of the obvious nutritional value of snail in human diet, no significant effort has been made at its large scale production as with other livestock like cattle, goat, sheep, and poultry. The main source of supply to the consumers is through marketers who gather them from the wild making the supply relatively higher during the rainy season than the dry season. FAO (1986) encouraged raising one's own snails, a practice referred to as 'snail farming' with the advantage of continuous supply of fresh snail meat whenever this is desired and sale of excess to other consumers [12].

For effective performance, nutrition in snail production cannot be underestimated. African giant land snails (A. marginata) are naturally herbivores. They feed mostly during the night because they are nocturnal animals. However experience has shown that they can eat at any time of the day if served with their delicacy in a cool, humid environment. Their conventional feed comprises of fresh leaves/shoots (pawpaw, lettuce, cabbage, cassava, cocoyam, African spinach, waterleaf); Ripe fresh fruits (pawpaw, banana, plantain, mango) and household/agro wastes (poultry litter, rice bran, palm kernel meal) etc. $[8,11]$. These are mostly of plant origin and there is possibility of scarcity during the dry season. Sourcing for these feeds in the urban areas may be very difficult. There is therefore the need to source for acceptable feed that is available all year round.

Feed accounts for at least $70 \%$ of total cost of livestock production. The high cost of producing animal products due to the exorbitant prices of feed ingredient has forced animal nutritionists to explore the use of agricultural byproducts hitherto referred to as wastes as feed resources in order to reduce cost of production [18].

There is paucity of information on quality feedstuffs for large scale production of snail. Hamzat (2004) evaluated the use of kola testa, a byproduct of kola fruit, for feeding snails in Nigeria [15]. Lettuce waste, an inedible foliage after harvesting was found to be cherished by snails. It is succulent and available all year round. Lettuce has been reported to contain water $(94 \mathrm{~g})$; energy $(18 \mathrm{kcal})$; protein $(1.3 \mathrm{~g})$; fat $(0.3 \mathrm{~g})$; carbohydrate $(3.5 \mathrm{~g})$; fibre $(1.9 \mathrm{~g})$ and ash $(0.9 \mathrm{~g})$ per $100 \mathrm{~g}$ of edible portion. It also contains $(\mathrm{mg}) \mathrm{Ca}$ (68); Fe (1.4); Mg (11); P (25); Cu (0.044) per 100g of edible portion [21]. There is a dearth of information on the use of lettuce waste by snails, hence this study was embarked upon to evaluate the performance of African giant land snail fed lettuce waste in comparison with cabbage waste and pawpaw leaves.

\section{Materials and Method}

One hundred and twenty (120) growing A. marginata snails of mean weight of $132.91 \pm 2.13 \mathrm{~g}$ were used for the experiment. The snails were randomly allotted into 4 dietary treatments of pawpaw leaves, whole lettuce, lettuce wastes and cabbage wastes. Each treatment was replicated thrice with 10 snails per replicate in a completely randomized design. The snails were reared in wooden cages of $0.5 \times 0.5 \times 0.5 \mathrm{~m} 3$ compartments. Feed and water were supplied ad libitum. Egg shell powder was added to the soil weekly to supply calcium. Feed intake and weight gain were measured on a daily and weekly basis respectively. Shell length and width were measured with vernier caliper while micrometer screw gauge was used to measure the shell thickness. Other parameters determined were mortality and feed conversion ratio. The feeding trial lasted six (6) months.

\subsection{Digestibility Trial}

Three (3) snails per replicate were put inside cages demarcated into different compartments devoid of soil but lined with foam. The snails were fed with the same diet fed during the feeding trial. Daily feed intake and excreta voided were recorded for each treatment. The daily excreta for each treatment was dried in the oven at $600 \mathrm{C}$ and dry matter determined. The trial lasted 10 days, including 3 days for acclimatization and 7 days for excreta collection.

\subsection{Carcass Analysis}

Nine growing snails per treatment ( 3 per replicate) were used at the end of the feeding trial for carcass analysis. The snails were starved overnight and their weights taken. They were killed by striking iron rod on their shell after which the visceral, shell, haemolymph and foot were separated. Parameters determined were: dressing percentage, visceral to live weight percent, shell to live weight percent and haemolymph per live weight percent.

\subsection{Chemical Analysis}

Proximate composition of the experimental diets as well as that of the foot of the snails was carried out [6]. Parameters analysed were dry matter, crude protein, crude fibre, ash and ether extract.

\subsection{Organoleptic Evaluation of the Cooked Meat}

The snail meat from each treatment was washed with alum and cooked separately in pots containing $3 \mathrm{~g}$ of salt dissolved in $300 \mathrm{mls}$ of water at $1000 \mathrm{c}$ for 20 minutes. A twelve -member taste panellist was set up. They were trained prior to serving of the meat. The snail meat from each treatment was served in individual plates and given to the panellist. They were also served with drinking water to rinse their mouth after tasting each treatment of the meat. There was partitioning in between the panellists in such a way that there was no interaction with one another. Questionnaires were given to the panellist for rating of the samples according to the method of Larmond (1977) [17]. The ratings were based on a 9 point hedonic scale of 1(dislike extremely) and 9(like extremely). The evaluation was based on colour, taste, flavour, tenderness, and overall 
acceptability.

\subsection{Data Analysis}

All data were subjected to analysis of variance while the treatment means were separated "using Duncan multiple range test (SAS 2003) [20]. All snails in the cage by replicate represent the experimental unit.

\section{Results}

\subsection{Proximate Composition of Test Ingredients.}

The proximate composition of experimental diets is as shown on Table 1. The crude protein of PL was significantly higher than that of the other test diets. Crude fibre and ash follow the pattern $\mathrm{WL}>\mathrm{PL}>\mathrm{LW}>\mathrm{CW}$ with $\mathrm{CW}$ recording the highest Nitrogen Free Extract (NFE) while PL had the lowest.

Table 1. Proximate composition of the snail diet (\% dry matter).

\begin{tabular}{|c|c|c|c|c|}
\hline Nutrients & Pawpaw Leaf (PL) & Whole Lettuce (WL) & Lettuce Waste (LW) & Cabbage Waste (CW) \\
\hline Dry matter & 25.43 & 5.96 & 7.04 & 10.10 \\
\hline Crude protein & 33.25 & 11.20 & 7.35 & 9.80 \\
\hline Crude fibre & 7.26 & 8.96 & 6.32 & 5.48 \\
\hline Ether extract & 0.78 & 0.56 & 0.27 & 0.23 \\
\hline Ash & 10.86 & 11.65 & 9.67 & 6.94 \\
\hline Nitrogen free extract & 47.85 & 67.63 & 76.39 & 77.55 \\
\hline
\end{tabular}

\subsection{Feeding and Growth Performance}

The results obtained for the feeding and growth performance for growing A. marginata snails is as presented in Table 2. The mean dry matter feed intake showed that there were significant differences among the treatment means $(\mathrm{P}<0.05)$. The mean weekly feed intake of $6.45,8.79,8.18$ and $7.81 \mathrm{~g}$ were recorded for snails placed on PL, WL, LW and CW respectively. The highest mean weekly feed intake was recorded in WL $(8.79 \mathrm{~g})$ while the lowest was recorded in PL (6.45g).

The weights gained by the experimental snails were affected by the dietary treatments $(\mathrm{P}<0.05)$. Snails on $\mathrm{CW}$ recorded the highest mean weekly weight gain of $3.55 \mathrm{~g}$ which was statistically similar to that of LW $(3.50 \mathrm{~g})$ while those on PL recorded the least weekly weight gain of $2.35 \mathrm{~g}$.

Treatment effect on monthly shell length gain was significant. It was observed that the highest mean monthly shell length gain of $3.85 \mathrm{~mm}$ occurred in snails on LW while the least value of $3.21 \mathrm{~mm}$ was recorded in snails on PL. The mean monthly shell length gain of snails on WL and CW were similar $(\mathrm{P}>0.05)$. There were also significant differences in the mean monthly shell width gain $(\mathrm{P}<0.05)$ with snails on $\mathrm{WL}$ recording the highest value of $3.26 \mathrm{~mm}$ which was statistically similar to that of LW $(3.13 \mathrm{~mm})$. Snails on PL recorded the lowest monthly shell width gain of $2.56 \mathrm{~mm}$. No significant differences were observed in the mean monthly shell thickness gain $(\mathrm{P}>0.05)$. The values ranged between 0.21 and $0.24 \mathrm{~mm}$.

The result of the dry matter digestibility showed significant differences amongst the treatments. The highest digestibility of $83.50 \%$ was recorded in snails on $\mathrm{CW}$ which was statistically similar to those on LW $(83.33 \%)$. The least digestibility of $78.33 \%$ was recorded in snails on PL.

The best feed per gain of 2.20 was obtained in snails on $\mathrm{CW}$ which was similar to that of snails on LW (2.34) while snails on PL recorded a value of 2.74 . No mortality was recorded in all the treatments.

Table 2. Performance characteristics of growing snails fed the experimental diets.

\begin{tabular}{|c|c|c|c|c|c|}
\hline Parameters (mean values) & Pawpaw Leaf (PL) & Whole Lettuce (WL) & Lettuce Waste (LW) & Cabbage Waste (CW) & SEM \\
\hline Weekly dry matter feed intake (g) & $6.45 \mathrm{~d}$ & $8.79 a$ & $8.18 b$ & $7.81 \mathrm{c}$ & 0.32 \\
\hline Initial weight (g) & 135.08 & 132.15 & 131.91 & 132.50 & 0.38 \\
\hline Final weight (g) & $191.48 b$ & $213.99 a$ & $215.97 \mathrm{a}$ & $217.60 \mathrm{a}$ & 1.95 \\
\hline Weekly weight gain $(\mathrm{g})$ & $2.35 \mathrm{c}$ & $3.41 \mathrm{~b}$ & $3.50 \mathrm{a}$ & $3.55 \mathrm{a}$ & 0.57 \\
\hline Total weight gain $(\mathrm{g})$ & $56.40 \mathrm{c}$ & $81.84 \mathrm{~b}$ & $84.06 \mathrm{a}$ & $85.10 \mathrm{a}$ & 2.05 \\
\hline Monthly shell length gain (mm) & $3.21 \mathrm{~b}$ & $3.60 \mathrm{a}$ & $3.85 \mathrm{a}$ & $3.65 \mathrm{a}$ & 0.20 \\
\hline Monthly shell width gain (mm) & $2.56 \mathrm{~d}$ & $3.26 \mathrm{a}$ & $3.13 b$ & $2.86 \mathrm{c}$ & 0.09 \\
\hline Mortality (\%) & 0.00 & 0.00 & 0.00 & 0.00 & \\
\hline Dry matter digestibility (\%) & $78.33 c$ & $81.18 b$ & $83.33 a$ & $83.50 \mathrm{a}$ & 0.71 \\
\hline Feed per gain & $2.74 a$ & $2.58 \mathrm{~b}$ & $2.34 \mathrm{c}$ & $2.20 \mathrm{~d}$ & 0.10 \\
\hline
\end{tabular}

$\mathrm{a}, \mathrm{b}, \mathrm{c}, \mathrm{d}$ : means along the same row with different superscripts are significantly different $(\mathrm{p}<0.05)$

SEM - Standard Error of Means

$\mathrm{n}=3$ per diet

\subsection{Carcass Analysis}

Table 3 presents results of foot yield, visceral, shell and haemolymph components of growing snails. The highest foot weight was recorded for snails on PL. There were significant differences $(\mathrm{P}<0.05)$ in the dressing percentages of the snails. 
The highest dressing percentage of $43.20 \%$ was obtained for snails on LW while the lowest value of $35.19 \%$ was recorded for snails on PL. The mean weight of the shell followed the same trend as the dressing percentage. The shell to live weight for snails PL and LW were similar and were significantly higher than the values obtained for snails on WL and CW.

Table 3. Carcass evaluation of growing snails (A. marginata) fed the experimental diets.

\begin{tabular}{|c|c|c|c|c|c|}
\hline Parameters (mean values) & $\begin{array}{l}\text { Pawpaw Leaf } \\
\text { (PL) }\end{array}$ & $\begin{array}{l}\text { Whole Lettuce } \\
\text { (WL) }\end{array}$ & $\begin{array}{l}\text { Lettuce Waste } \\
(\mathrm{LW})\end{array}$ & $\begin{array}{l}\text { Cabbage Waste } \\
(\mathrm{CW})\end{array}$ & SEM \\
\hline Number of snails & 9 & 9 & 9 & 9 & \\
\hline Live weight (g) & $190.80^{\mathrm{b}}$ & $211.70^{\mathrm{a}}$ & $210.90^{\mathrm{a}}$ & $213.20^{\mathrm{a}}$ & 1.98 \\
\hline Foot (edible portion) (g) & $67.14^{\mathrm{d}}$ & $85.17^{\mathrm{b}}$ & $91.11^{\mathrm{a}}$ & $82.38^{\mathrm{c}}$ & 2.48 \\
\hline Visceral (g) & $42.42^{\mathrm{a}}$ & $38.50^{\mathrm{b}}$ & $39.60^{\mathrm{b}}$ & $41.12^{\mathrm{a}}$ & 2.07 \\
\hline Shell (g) & $50.84^{\mathrm{b}}$ & $51.40^{\mathrm{b}}$ & $54.10^{\mathrm{a}}$ & $51.10^{\mathrm{b}}$ & 1.68 \\
\hline Haemolymph (ml) & $30.40^{\mathrm{b}}$ & $36.63^{\mathrm{a}}$ & $26.09^{\mathrm{c}}$ & $38.60^{\mathrm{a}}$ & 1.26 \\
\hline Dressing (\%) & $35.19^{d}$ & $40.23^{\mathrm{b}}$ & $43.20^{\mathrm{a}}$ & $38.64^{\mathrm{b}}$ & 1.09 \\
\hline Shell/live weight (\%) & $26.65^{\mathrm{a}}$ & $24.28^{\mathrm{b}}$ & $25.65^{\mathrm{a}}$ & $23.97^{\mathrm{b}}$ & 0.75 \\
\hline Visceral/live weight (\%) & $22.23^{\mathrm{a}}$ & $18.19^{\mathrm{b}}$ & $18.78^{\mathrm{b}}$ & $19.29^{\mathrm{b}}$ & 1.01 \\
\hline Haemolymph/live weight (\%) & $15.93^{\mathrm{b}}$ & $17.30^{\mathrm{a}}$ & $12.37^{\mathrm{c}}$ & $18.10^{\mathrm{a}}$ & 1.39 \\
\hline
\end{tabular}

a,b,c,d: means along th same row with different superscripts are significantly different $(\mathrm{p}<0.05)$, SEM - Standard Error of Means

\subsection{Nutrient Composition of the Meat}

The percentage crude proteins in all the treatments were similar with values ranging from 17.82 to $18.53 \%$ (Table 4 ). The percentage ash contents ranged between 2.14 and 2.33 and the differences among the treatments were not significant.
The values obtained for the fat content were also similar and ranged between 2.11 and 2.44. There was however significant differences in the nitrogen free extract with the highest value of $3.85 \%$ obtained for snails on $\mathrm{CW}$ while the lowest $(2.80 \%)$ was recorded for snails on WL.

Table 4. Nutrient composition ( $\mathrm{g} / 100 \mathrm{~g}$ fresh meat) of snail meat from growing snails fed the experimental diets.

\begin{tabular}{|c|c|c|c|c|c|}
\hline Nutrient (\%) & Pawpaw Leaf (PL) & Whole Lettuce (WL) & Lettuce Waste (LW) & Cabbage Waste (CW) & SEM \\
\hline Dry matter & 26.33 & 25.89 & 25.32 & 26.01 & 0.11 \\
\hline Moisture content & 73.67 & 74.11 & 74.68 & 73.99 & 0.13 \\
\hline Crude protein & 18.53 & 18.32 & 17.95 & 17.82 & 0.08 \\
\hline Ash & 2.26 & 2.33 & 2.14 & 2.23 & 0.02 \\
\hline Ether extract & 2.31 & 2.44 & 2.21 & 2.11 & 0.03 \\
\hline Nitrogen free extract & $3.23^{\mathrm{b}}$ & $2.80^{\mathrm{b}}$ & $3.02^{\mathrm{b}}$ & $3.85^{\mathrm{a}}$ & 0.06 \\
\hline
\end{tabular}

a,b: means along the same row with different superscripts are significantly different $(\mathrm{p}<0.05)$

SEM - Standard Error of Means

\subsection{Organoleptic Evaluation of Cooked Meat}

The dietary treatments had no significant effect on the colour, taste, flavour, texture and overall acceptability of the snail meat (Table 5).

Table 5. Organoleptic properties of snail meat from growing snails fed the experimental diets.

\begin{tabular}{|c|c|c|c|c|c|}
\hline Properties & $\begin{array}{l}\text { Pawpaw } \\
\text { Leaf } \\
(\mathrm{PL})\end{array}$ & $\begin{array}{l}\text { Whole } \\
\text { Lettuce } \\
\text { (WL) }\end{array}$ & $\begin{array}{l}\text { Lettuce } \\
\text { Waste } \\
\text { (LW) }\end{array}$ & $\begin{array}{l}\text { Cabbage } \\
\text { Waste (CW) }\end{array}$ & SEM \\
\hline Colour & 7.34 & 7.58 & 7.92 & 7.39 & 0.07 \\
\hline Taste & 8.65 & 8.31 & 8.14 & 8.62 & 0.06 \\
\hline Flavour & 8.11 & 8.34 & 8.94 & 8.03 & 0.10 \\
\hline Texture & 8.62 & 8.57 & 8.62 & 8.42 & 0.02 \\
\hline $\begin{array}{l}\text { Overall } \\
\text { acceptability }\end{array}$ & 8.45 & 8.21 & 8.50 & 8.55 & 0.04 \\
\hline
\end{tabular}

SEM - Standard Error of Means

\section{Discussion}

The findings of this study were similar to those obtained in an earlier experiment reported by Babalola and Akinsoyinu,
2010 for snailets fed the same set of experimental diets. The zero mortality recorded in all the treatments indicates that growing snails are more resilient than their snailets counterpart which recorded some mortality [10]. This means that any of the feed could be used in feeding growing snails without adverse effect.

Snails on LW recorded the highest shell weight and also high shell per live weight. This may be as a result of the high mineral content of LW most especially calcium which supported shell growth [21]. LW also enhanced the highest dressing percentage. The organoleptic properties of the snail meat were similar, an indication that the feed had no appreciable effect on the meat quality of the snails.

Snailets are better converter of the experimental feeds than their growing counterparts as the values obtained for the feed conversion ratio of snailets were generally lower than those obtained for the growing snails. One can therefore suggest the feeding of these plant wastes to snailets and as they grow older supplementing with compounded ration to meet their energy needs.

It can be concluded that lettuce wastes contain high nutrients which favour snail growth and development as 
evidenced in the total weight gain, feed per gain, shell weight and dressing percentage and incorporation of the dried lettuce waste into the feed could enhance better growth of snails and increase in the supply of animal protein in Nigeria and so prevent these animals from going into extinction.

\section{Acknowledgement}

The author is grateful to Landmark University, Omu-Aran for providing a conducive environment to embark on the write-up.

\section{References}

[1] O.M. Adesope, Attitudes of household in a Niger Delta zone towards snail meat consumption. In: Ukachukwu S.N. et al. (eds). Animal production in the new millennium. Challenges and options. Zaria: NSAP secretariat. 2000.

[2] S.S. Ajayi, O.O. Tewe, C. Moriaty and M.O. Awesu, Observation on the biological and nutritive value of the African giant snail, Archachatina marginata. East Africa Wildlife J. Vol. 16 pp 85-95. 1978.

[3] O. Akinnusi, Snail farming - low investment, high profit business. Livestock Echo April-June pp14-23. 1997.

[4] O. Akinnusi, Snail rearing - Case study Abeokuta, Ogun State, Nigeria. Proceedings of 5th Annual Conference of Animal Science Association of Nigeria, Port Harcourt Nigeria, Sept. 19-22. 2000.

[5] O. Akinnusi, Introduction to snails and snail farming. Triolas publishing company, Abeokuta, p.70. 2002.

[6] Association of Official Analytical Chemist (A.O.A.C). Official methods of analysis, Washington DC. 2005.

[7] M.O. Awesu, A biology and management of the African giant land snail (A.marginata). M.Phil. Thesis, University of Ibadan, Nigeria. 1980.

[8] I.A. Ayodele and A.A. Asimalowo, Essentials of snail farming. Agape Printers, Ibadan. Pp 7-37. 1999.

[9] O.O. Babalola and A.O. Akinsoyinu, Proximate composition and Mineral Profile of Snail meat from different Breeds of Land Snail in Nigeria. Pakistan Journal of Nutrition Vol. 8(12): 1842-1844. 2009.
[10] O.O. Babalola and A.O. Akinsoyinu, Performance, carcass analysis and sensory evaluation of cooked meat of snailets of African giant land snail (Archachatina marginata) fed pawpaw leaves, whole lettuce, lettuce waste and cabbage waste as sole feed ingredient. African Journal of Agricultural Research Vol. 5(17): 2386-2391. 2010

[11] O.O. Babalola and E.E. Owolabi, Comparative evaluation of performance of snails (Archachatina marginata) fed milk leaf (Euphorbia heterophylla) as against pawpaw leaf (Carica papaya) and Concentrate as sole feed. International Journal of Research in Applied, Natural and Social Sciences Vol. 2(11), pp 137-144. 2014.

[12] FAO, Farming snails by FAO. Better Farming Series, 3/33 Rome, Italy. 1986.

[13] FAO, Proximate composition of FOODS. In: Improving nutrition through home gardening. A training package for preparing field worker in Africa. Food and Nutrition Division, FAO. United Nations, Rome. Appendix 2. 2001.

[14] Food and Agricultural Organisation (FAO), Trade book. Vol. 23. Rome Italy. 1969.

[15] R.A. Hamzat, Utilization of Testa of kola (Cola nitida) in the feeding of African giant land snail (Archachatina marginata) in Southwestern Nigeria. PhD Thesis, University of Ibadan. 2004.

[16] E.A. Imevbore and A.A. Ademosun, The nutritive value of the African giant land snail, Archachatina marginata. J. Animal. Prod. Res. Vol. 8 (2), 76-87. 1988.

[17] E. Larmond, Laboratory methods for sensory evaluation of food. Research Branch. Canadian Department of Agriculture 1637 pp. 50-59. 1977.

[18] O.G. Longe and Fagbenro-Bryon, Composition and physical characters of some fibrous waste and by-products for pig feed in Nigeria. Biets, Trop. Landwirthsch Vet. Med. Vol. 28 pp. 199-205. 1990.

[19] A.J. Omole, How to start and manage snail farming. A paper presented at the workshop organized by Petroleum Staff Training Programme for Retiree at Petroleum Training Institute, Effunrun-Warri, Delta State on March 13-15th 2001.

[20] S.A.S, Version 8 Edition, Statistical Analysis System Institute Inc. Carry, N.C. USA. 2003.

[21] USDA, USDA Nutrient Database for standard Reference, Release 12. 1998. 